\title{
Diet of 0+ brown trout (Salmo trutta L., 1758) from the river Erro (Navarra, north of Spain)
}

\author{
J. Oscoz ${ }^{1,3}$, P. M. Leunda ${ }^{1}$, F. Campos $^{2}$, M. C. Escala ${ }^{1}$ and R. Miranda ${ }^{1}$ \\ ${ }^{1}$ Dpto. de Zoología y Ecología, Facultad de Ciencias, Universidad de Navarra, Apdo. 177, \\ E-31080, Pamplona, España. \\ ${ }^{2}$ Universidad Europea Miguel de Cervantes, c/ Padre Julio Chevalier 2, E-47012, Valladolid, España \\ 3 E-mail: joscoz@alumni.unav.es
}

\begin{abstract}
The diet composition of 41 0+ brown trout (Salmo trutta L., 1758) (33-97 mm TL) captured in August 2002 in the Erro River (North of Spain) is described. The diet was mainly composed by aquatic invertebrates. Excluding nematodes because they are possible parasites, the most consumed prey items were mayflies, dipterans, and crustaceans. Fingerling brown trout refused Chironomidae, Elmidae, and terrestrial invertebrates from the drift, and Elmidae, Heptageniidae, and Leuctridae from the benthos, while they showed preference for Rhyacophilidae from the benthos. Fingerling brown trout seems to act as an opportunistic predator, and the consumption of different preys seems to be influenced by their accessibility, predation risk, and their energetic value.
\end{abstract}

Keywords: Fingerling, brown trout, feeding, prey selection, drift, benthos.

\section{RESUMEN}

Se analizó la dieta de 41 alevines de trucha común (Salmo trutta L., 1758) (33-97 mm LT) del río Erro (Norte de España). Su alimentación estuvo constituida principalmente por invertebrados acuáticos. Si no se tiene en cuenta a los nematodos por la posibilidad de tratarse de parásitos, las presas más consumidas fueron efémeras, dipteros y crustáceos. Los alevines de trucha común rechazaron los quironómidos, élmidos y los invertebrados terrestres de la deriva, así como los élmidos, heptagénidos y leúctridos del bentos, mientras que mostraron preferencia por los riacofilidos del bentos. Los alevines de trucha común parecen comportarse como depredadores oportunistas, pareciendo estar el consumo de las diferentes presas influenciado por su accesibilidad, el riesgo de predación y el valor energético de cada presa.

Palabras clave: alevines, trucha común, alimentación, selección de presas, deriva, bentos.

\section{INTRODUCTION}

The brown trout (Salmo trutta L., 1758) is a species of great interest because it is prized by anglers and has high economic value. The study of its feeding habits is one of the basic ways of understanding its biology. The analysis of its diet, apart from indicating its trophic requirements, provides us with indirect information about how it feeds, its possible interaction with other species (competition, predation), and also the manner in which it occupies its habitat (García de Jalón, 1985; García De Jalón \&
Barceló, 1987; Smith et al., 1993). In addition, a study of its diet gives information about the amount of energy consumed by brown trout (Elliott, 1994) and when food becomes a limiting factor, aiding in stock management (Lobón-Cerviá \& Fitzmaurice, 1988; García de Jalón, 1993; Vehanen et al., 1998).

There is ample bibliography which analyses the feeding habits of this species in Spain and the rest of Europe together with the variation in size of the brown trout (Lobón-Cerviá et al., 1985; Montañés \& Lobón-Cerviá, 1986; García de Jalón \& Barceló, 1987; Greenberg et 
al. 1997). However, some studies do not agree on whether its food is primarily composed of prey obtained from drift (Tippets \& Moyle, 1978; Dahl, 1998; Degerman et al., 2000) or from benthos (Neveu, 1980; Haugen \& Rygg, 1996; Kreivi et al., 1999).

In Navarra, where there are some $1600 \mathrm{~km}$ of trout streams, angling for brown trout is of great importance, but to date only one study has been carried out on the feeding habits of this species in the Larraun River (Oscoz et al., 2000). The aim of this paper is to report the feeding habits of $0+$ brown trout in a river of this region and its relationship to benthos and drift.

\section{MATERIAL AND METHODS}

This study was carried out in the Erro River, which is a tributary of the Irati River (Ebro basin) (Fig. 1). The Erro River is $48 \mathrm{~km}$ long and drains an area of $214 \mathrm{~km}^{2}$. In the upper reaches it flows through beech forest, and later through meadow areas with oak trees, with many willows and alder trees along its banks. The final stretch of the Erro River flows through cultivated land, with wooded banks of willow, poplar and ash.

European minnow (Phoxinus phoxinus (L., 1758)) occurs with the brown trout in the studied river stretch, but barbel (Barbus haasi Mertens, 1924), stone loach (Barbatula barbatula L., 1758), French nase (Chondrostoma toxostoma Steindachner, 1866), Graells barbel (Barbus graellsii Steindachner, 1866), lamprehuela (Cobitis calderoni Bacescu, 1961), and gudgeon (Gobio gobio L., 1758) are also present in the Erro River.

The river reach sampled was located on the upper course of the Erro River $\left(43^{\circ} 0^{\prime} \mathrm{N} 1^{\circ} 24^{\prime} \mathrm{W}\right.$ and $\left.42^{\circ} 58^{\prime} \mathrm{N} 1^{\circ} 24^{\prime} \mathrm{W}\right)$, its altitude ranging from $810 \mathrm{~m}$ to $760 \mathrm{~m}$. The study area combined lentic and lotic areas, and a mean water surface width of $4 \mathrm{~m}$ in the upper stretch and $8 \mathrm{~m}$ in the lower stretch. The substratum was dominated by small boulders and cobbles, interspersed with gravel and boulders. The riparian vegetation was abun-

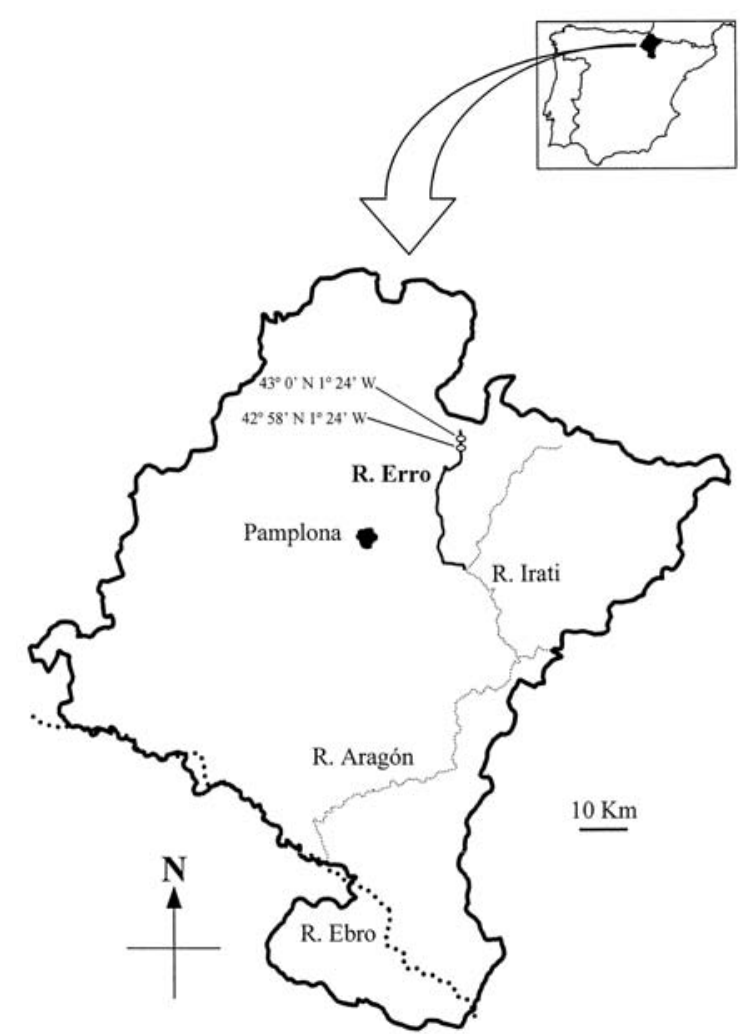

Figure 1. Location of the Erro River in Navarra. Localización del río Erro en Navarra.

dant, allowing for an important cover. The stomach contents of 41 brown trout (33-97 mm total length (TL)) caught by electro-fishing surveys in the river stretch in August 2002 were analysed. They were all caught before midday, so as to eliminate possible variation in consumption of prey throughout the day (Neveu, 1980). After capture they were taken in cold storage to the laboratory, where they were frozen for later study. The stomachs were removed and preserved in $4 \%$ formaldehyde. The stomach analyses were restricted to prey items found in the stomach and oesophagus so as to increase the likelihood that the prey had been eaten recently, and therefore in the habitat where the fish were caught (Wennhage \& Pihl, 2002). Prey items were examined under a stereoscopic microscope (x7-45). Two types of prey were found: terrestrial invertebrates (insects) and aquatic invertebrates. In the later group, the prey was identified to the family level, when possible. 
In animal prey items, the frequency of occurrence of a given prey type is defined as the number of stomachs in which that prey occurs, expressed as a frequency of the total number of stomachs in which the prey are present (Hynes, 1950). The relative abundance of a prey (or contribution to the stomach contents) is defined as the percentage of total stomach contents in all predators comprised by the given prey. In mathematical terms, the percentage occurrence $\left(\% F_{i}\right)$ and the percentage abundance $\left(\% A_{i}\right)$ of prey type $i$ can be described by the equations:

$$
\% F_{i}=\left(N_{i} / N\right) \times 100
$$

where $N_{i}$ is the number of predators with prey $i$ in their stomach, $N$ is the total number of predators with stomach contents of any kind;

$$
\% A_{i}=\left(\Sigma S_{i} / \Sigma S_{t}\right) \times 100
$$

where $S_{i}$ is the stomach content (number) composed by prey $i$, and $S_{t}$ the total stomach content of all stomach in the entire sample (Amundsen et al., 1996).

The diet diversity of the sampled population $\left(H^{\prime}\right)$ was calculated using the Shannon-Wienner diversity index $\left(H^{\prime}=-\Sigma p_{i} \cdot \log _{2} p_{i}\right)$, where $p_{i}$ is the proportion of the prey item $i$ among the total number of preys. The use of the Shannon-Wienner index provides a relatively objective indication of niche breadth (Marshall \& Elliott, 1997). Furthermore, in order to evaluate specialization in the diet of the brown trout, evenness index $\left(E=H^{\prime} / H^{\prime}{ }_{\max }\right)$ was determined, considering that values close to zero mean a stenophagous diet and those closer to one more of a euryphagous diet.

In order to analyse if the $0+$ brown trout selected their prey, samples of benthic and drift macroinvertebrates were taken on the same day and in the same place as the trout, in order to compare them with the diet. The sample was obtained with a hand net $(25 \times 28 \mathrm{~cm}$ with a $0.1-\mathrm{mm}$ mesh) from the benthos, and from the drift with a net $(33 \times 28 \mathrm{~cm}$ with a $0.25-\mathrm{mm}$ mesh), which was left in place for 45-60 min; this duration should yield reasonably represen- tative samples (Culp et al., 1994). In order to evaluate the possible prey selection from benthos or drift, the $W$ Savage (1931) selection index was used ( $W=A_{i} / D_{i}$, where $A_{i}$ is the trout use of the resource $i$, and $D_{i}$ the availability of that resource in the river). The values of $W$ vary between 0 and $\infty$, where 1 is the non-selected value. This index is more objective than other similar ones, as it allows the checking of statistical significance by comparing with an $\chi^{2}$ with one degree of freedom (Manly et al., 1993).

\section{RESULTS}

Of the 41 stomachs examined, three were empty and therefore were not taken into account in later analyses. In the remaining 38 stomachs 215 prey were found, mostly aquatic invertebrates (Table 1). The most abundant prey in the diet were nemato-

Table 1. Diet composition ( $\% F_{i}$ : occurrence and $\% A_{i}$ : abundance), trophic diversity $\left(H^{\prime}\right)$, and evenness index $(E)$ values of $0+$ brown trout in the Erro River. Composición de la dieta $\left(\% F_{i}\right.$ : frecuencia and $\% A_{i}$ : abundancia), diversidad trófica $\left(H^{\prime}\right)$ e indice de equitatividad (E) de los alevines de trucha común en el río Erro.

\begin{tabular}{lrr}
\hline Taxon & $\boldsymbol{\%}_{\boldsymbol{i}}$ & $\boldsymbol{\%}_{\boldsymbol{i}}$ \\
\hline AQUATIC INVERTEBRATES & & \\
Nematoda & 55.26 & 42.33 \\
Gammaridae & 18.42 & 9.30 \\
Hydraenidae & 2.63 & 0.47 \\
Chironomidae & 28.95 & 8.37 \\
Baetidae & 39.47 & 13.02 \\
Ephemerellidae & 7.90 & 1.40 \\
Heptageniidae & 47.37 & 12.09 \\
Ephemeroptera (unidentified) & 5.26 & 0.93 \\
Leuctridae & 18.42 & 3.26 \\
Hydropsychidae & 7.90 & 1.86 \\
Glossosomatidae & 7.90 & 1.40 \\
Polycentropodidae & 5.26 & 0.93 \\
Rhyacophilidae & 7.90 & 1.40 \\
Total & 100.00 & 96.76 \\
TERRESTRIAL INVERTEBRATES & & \\
Trichoptera & 7.90 & 1.39 \\
Ephemeroptera & 7.90 & 1.39 \\
Insecta (unidentified) & 2.63 & 0.46 \\
Total & 15.79 & 3.24 \\
\hline Trophic diversity (H') & \multicolumn{2}{c}{2.79} \\
Evenness index (E) & \multicolumn{2}{c}{0.70} \\
\hline
\end{tabular}


des $(42.3 \%)$, mayflies $(27.3 \%)$, gamarids $(9.3 \%)$, and chironomids $(8.4 \%)$. The $0+$ brown trout consumed few terrestrial invertebrates $(3.2 \%)$. If we exclude nematodes from the analysis, as they may be trout parasites and not prey (Molloy et al., 1995; Brotheridge et al., 1998; Byrne et al., 2002), mayflies, crustaceans, dipterans, and trichopterans were the most consumed prey items.

The trophic diversity of $0+$ brown trout was relatively high $\left(H^{\prime}=2.79\right.$, Table 1$)$, as was its evenness index $(E=0.70)$, which indicates that they tend to be euriphagic. This fact was more obvious when nematodes were not included as prey, in which case the values for trophic diversity and evenness were notably higher $\left(H^{\prime}=3.13\right.$ and $\left.E=0.80\right)$.

Table 2 shows benthic prey selection of $0+$ brown trout, according to the Savage index $(W)$, and the posterior statistical comparison of the prey availability $\left(D_{i}\right)$ in the benthic macroinvertebrate assemblage or in the river drift, as well as its use $\left(A_{i}\right)$. In benthos, fingerling brown trout positively selected Rhyacophilidae, whereas Elmidae, Heptageniidae, and Leuctridae were avoided. On the other hand, with reference to those macroinvertebrates present in the drift, the fingerling brown trout refused Elmidae, Chironomidae, and terrestrial invertebrates, but did not show positive selection for any taxon. The consumption of other items did not show significant selection.

\section{DISCUSSION}

The diet of fingerling brown trout in the Erro River is mainly composed of aquatic invertebrates, as has been described in other studies

Table 2. Prey selection by $0+$ brown trout from the Erro River. $A_{i}$ : abundance; $D_{i}$ : availability; $W$ : Savage index; ** $\mathrm{P}<0.01$. The significance levels were obtained applying Bonferroni's correction ( $\alpha$ /number of categories). Selección de presas por parte de los alevines de trucha común en el río Erro. $A_{i}$ : abundancia; $D_{i}$ : disponibilidad; $W$ : índice de Savage; $* * P<0.01$. Los niveles de significación se calcularon mediante la corrección de Bonferroni ( $\alpha$ /número de categorías).

\begin{tabular}{|c|c|c|c|c|c|c|c|}
\hline \multirow[b]{2}{*}{ Taxon } & \multirow[b]{2}{*}{$A_{i}$} & \multicolumn{2}{|c|}{ Benthos } & & \multicolumn{2}{|c|}{ Drift } & \\
\hline & & $D_{i}$ & W & & $D_{i}$ & $\boldsymbol{W}$ & \\
\hline Baetidae & 11.41 & 14.72 & 0.78 & ns & 7.18 & 1.59 & ns \\
\hline Caenidae & & 1.60 & 0.00 & ns & & & \\
\hline Chironomidae & 12.08 & 16.91 & 0.71 & ns & 28.70 & 0.42 & ** \\
\hline Elmidae & & 9.85 & 0.00 & $* *$ & 9.86 & 0.00 & $* *$ \\
\hline Ephemerellidae & 2.01 & 2.19 & 0.92 & ns & 1.35 & 1.49 & ns \\
\hline Gamaridae & 2.69 & 2.44 & 1.10 & ns & & & \\
\hline Glossossomatidae & 2.01 & 1.93 & 1.04 & ns & 6.73 & 0.30 & ns \\
\hline Heptageniidae & 11.41 & 22.62 & 0.50 & $*$ & 11.66 & 0.98 & $\mathrm{~ns}$ \\
\hline Hidracarina & & 0.42 & 0.00 & ns & 3.59 & 0.00 & ns \\
\hline Hydraenidae & 0.67 & 0.59 & 1.14 & ns & 0.45 & 1.49 & ns \\
\hline Hydropsychidae & 1.34 & 0.93 & 1.44 & ns & 3.14 & 0.43 & $\mathrm{~ns}$ \\
\hline Leptophlebiidae & & 1.34 & 0.00 & ns & & & \\
\hline Leuctridae & 4.70 & 18.08 & 0.26 & ** & 1.79 & 2.63 & ns \\
\hline Limoniidae & & 0.68 & 0.00 & ns & 0.90 & 0.00 & ns \\
\hline Nematoda & 44.30 & & & & & & \\
\hline Nemouridae & & 0.25 & 0.00 & ns & 0.45 & 0.00 & ns \\
\hline Oligochaeta & & 1.43 & 0.00 & ns & & & \\
\hline Planariidae & & 1.60 & 0.00 & $\mathrm{~ns}$ & & & \\
\hline Polycentropodidae & 1.34 & & & & 0.45 & 2.98 & ns \\
\hline Rhyacophilidae & 1.34 & 0.09 & 14.89 & ** & 0.45 & 2.98 & ns \\
\hline Sericostomatidae & & 0.85 & 0.00 & $\mathrm{~ns}$ & & & \\
\hline Simuliidae & & 0.17 & 0.00 & ns & 2.24 & 0.00 & ns \\
\hline Other aquatic invertebrates & & 1.33 & 0.00 & ns & 2.69 & 0.00 & ns \\
\hline Terrestrial invertebrates & 4.70 & & & & 18.38 & 0.26 & ** \\
\hline
\end{tabular}


(Neveu, 1980; Montañes \& Lobón-Cerviá, 1986; Kreivi et al., 1999; Oscoz et al., 2000). The apparently high consumption of nematodes may not be accurate due to the possibility that some could be trout parasites (Molloy et al., 1995; Brotheridge et al., 1998; Byrne et al., 2002) as well as parasites of dipteran larvae (Tachet et al., 1984), which may be eaten by the trout. Further studies would be necessary in order to determine if the $0+$ trout really consume such a large quantity of nematodes, or if it is a parasitic species.

Excluding the nematodes, the diet of the $0+$ brown trout in the Erro River consists principally of mayflies, a fact which has been noted in earlier studies (Neveau \& Thibault, 1977; Montañes \& Lobón-Cerviá, 1986; Oscoz et al., 2000). However, there were variations in the relative importance of some other items. Thus, in the Erro River the fingerling brown trout consumed more dipterans and fewer trichopterans than in the Larraun River (Oscoz et al., 2000), whereas in the Ucero and Avión-Milanos Rivers, they consumed more crustaceans and fewer dipterans and trichopterans (Lobón-Cerviá et al., 1985). These slight differences are probably due to the different availability of prey and the habitat differences between rivers (Power, 1992; Rutledge \& Power, 1992). In the Erro River the fingerling brown trout had a typical generalistic diet, as has been stated in other studies done on its feeding patterns (Haugen \& Rygg, 1996; Jorgensen et al., 2000).

With reference to prey selection, the rejection of elmids, in both drift and benthos, may be due to their lower energetic value because of their intense sclerotisation, (Power, 1992; Oscoz et al., 2000; 2001). Moreover, since trouts are visual predators, smaller preys (i.e., quironomids in drift) or those that camouflage or hide in the substratum (i.e., leuctrids and heptagenids) are more difficult to detect, so a lower consumption of these items would be expected (Rajasilta \& Vuorinen, 1983; Rincón \& Lobón-Cerviá, 1999), as observed in the Rainbow trout (Oncorhynchus mykiss (Walbaum, 1792) in the Urederra River (Oscoz et al., 2005). In this way, we could expect a higher use of drift preys, because there is a greater probability of detection of larger prey in the drift (Rincón \& Lobón-Cerviá, 1995). However, fingerling brown trout could have a more benthic diet, probably because feeding at the bottom of the river implies less risk from predators than feeding at the surface (Vollestad \& Andersen, 1985; Haugen \& Rygg, 1996; Oscoz et al., 2005). Besides, gape limitation and prey handling limitations play an important role in smaller species of fish, determining prey size selection (Keeley \& Grant, 1997), and consequently the higher or lower use of drift or benthos.

Moreover, we cannot ignore the absolute nutrient content and the ability to assimilate nutrients, as well as the risks involved in the capture of prey (Vinyard, 1980; Pillans et al., 2004). This could explain the positive choice of Rhyacophilidae in benthos, together with the negative response to terrestrial insects in the drift, a fact that has also been seen in Finnish rivers (Kreivi et al., 1999). Rhyacophilidae are prey with a high energetic content (Penczak et al., 1984), and their consumption implies lower risk from predators than the capture of preys on the surface, as they are mainly found in benthos (Vollestad \& Andersen, 1985; Haugen \& Rygg, 1996). This lower risk from predators implied in benthonic feeding is probably the reason for selecting these preys. However, given the opportunistic character of the salmonids (Keeley \& Grant, 1997; Vignes, 1998), when there is a large amount of drifting prey, this trophic resource will also be used (Kreivi et al., 1999).

Recent studies (McLaughlin et al., 1994; 1999) suggest the existence of two different feeding strategies in fingerling brook trout (Salvelinus fontinalis (Mitchell, 1815)): a) more sedentary individuals whose diet is based on benthonic prey and b) more active individuals that feed on surface prey. A more detailed study in more habitats would be necessary to discover if this also occurs among brown trout.

\section{ACKNOWLEDGEMENTS}

This research was carried out as part of the project "Actuaciones humanas en ríos de Navarra. 
$\mathrm{Su}$ incidencia en la conservación de la biodiversidad" supported by the CSIC and the Government of Navarra. We thank G. Telletxea, M. Rodríguez, and E. Garayoa for assistance with the electro-fishing.

\section{REFERENCES}

AMUNDSEN, P. A., H. M. GABLER \& F. J. STALDVIK. 1996. A new approach to graphical analysis of feeding strategy from stomach contents data - modification of the Costello (1990) method. J. Fish Biol., 48: 607-614.

BROTHERIDGE, R. M., K. E. NEWTON \& S. W. EVANS. 1998. Presence of a parasitic nematode (Eustrongylides sp.) in brown trout (Salmo trutta) from a heavy metal contaminated aquatic ecosystem. Chemosphere, 37 (14-15): 2921-2934.

BYRNE, C. J., C. V. HOLLAND, R. POOLE \& C. R. KENNEDY. 2002. Comparison of the macroparasite communities of wild and stocked brown trout (Salmo trutta L.) in the west of Ireland. Parasitology, 124: 435-445.

CULP, J. M., G. J. SCRIMGEOUR \& C. E. BEERS. 1994. The effect of sample duration on the quantification of stream drift. Freshw. Biol., 31: 165-173.

DAHL, J. 1998. Effects of a benthivorous and a driftfeeding fish on a benthic stream assemblage. Oecologia, 116: 426- 432

DEGERMAN, E., I. NASLUND \& B. SERS. 2000. Stream habitat use and diet of juvenile (0+) brown and grayling in sympatry. Ecol. Freshw. Fish, 9: 191-201.

ELLIOTT, J. M. 1994. Quantitative ecology and the brown trout. Oxford: Oxford University Press. $286 \mathrm{pp}$.

GARCIAA DE JALÓN, D. 1985. Efectos de la regulación de caudales en las poblaciones de Salmónidos fluviales. I Simposio Internacional de Estudio, Conservación y Utilización Racional de Áreas de Pesca de Salmónidos, Pamplona: 106-110.

GARCÍA DE JALÓN, D. 1993. La gestión de la pesca en las aguas dulces. Congreso Forestal Español, Lourizán, Pontevedra, 4: 75-81.

GARCÍA DE JALÓN, D. \& E. BARCELÓ. 1987. Estudio sobre la alimentación de la trucha común en ríos pirenaicos. Ecología, 1: 263-269.

GREENBERG, L. A., E. BERGMAN \& E. EKLOV. 1997. Effects of predation and intraspecific interac- tions on habitat use and foraging by brown trout in artificial streams. Ecol. Freshw. Fish, 6: 16-26.

HAUGEN, T. O. \& T. A. RYGG. 1996. Food- and habitat-segregation in sympatric grayling and brown trout. J. Fish Biol., 49: 301-318.

HYNES, H. B. N. 1950. The food of fresh-water sticklebacks (Gasterosteus aculeatus and Pygosteus pungitius), with a review of methods used in studies of the food of fishes. J. Anim. Ecol., 19: 36-58.

JORGENSEN, L., M. HALVORSEN \& P. A. AMUNDSEN. 2000. Resource partitioning between lake-dwelling Atlantic salmon (Salmo salar L.) and Artic charr (Salvelinus alpinus (L.)). Ecol. Freshw. Fish, 9: 202-209.

KEELEY, E. R. \& J. W. A. GRANT. 1997. Allometry of diet selectivity in juvenile Atlantic salmon (Salmo salar). Can. J. Fish. Aquat. Sci., 54: 18941902.

KREIVI, P., T. MUOTKA, A. HUUSKO, A. MAKIPETAYS, A. HUHTA \& K. MEISSNER. 1999. Diel feeding periodicity, daily ration and prey selectivity in juvenile brown trout in a subartic river. $J$. Fish Biol., 55: 553-571.

LOBÓN-CERVIÁ, J. \& P. FITZMAURICE. 1988. Stock assessment, production rates and food consumption in four contrasting Irish populations of brown trout (Salmo trutta L.). Pol. Arch. Hydrobiol., 35 (3-4): 497-513.

LOBÓN-CERVIÁ, J., C. MONTAÑÉS \& A. DE SOSTOA. 1985. Production and food consumption of a population of brown trout (Salmo trutta L.) in an aquifer-fed stream of Old Castile (Spain). Proceedings IVth British Freshwater Fisheries Conference, Liverpool: 41-51.

MANLY, B., L. MCDONALD \& D. THOMAS. 1993. Resource selection by animals. Statistical design and analysis for field studies. London: Chapman \& Hall. 177 pp.

MARSHALL, S. \& M. ELLIOTT. 1997. A comparison of univariate and multivariate numerical and graphical techniques for determining inter- and intraspecific feeding relationships in estuarine fish. J. Fish Biol., 51: 526-545.

McLAUGHLIN, R. L., M. M. FERGUSON \& D. L. G. NOAKES. 1999. Adaptative peaks and alternative foraging tactics in brook charr: evidence of shortterm divergent selection for sitting-and waiting and actively searching. Behav. Ecol. Sociobiol., 45: 386-395.

McLAUGHLIN, R. L., J. W. A. GRANT \& D. L. KRAMER. 1994. Foraging movements in relation to 
morphology, water-column use, and diet for recently emerged brook trout (Salvelinus fontinalis) in still-water pools. Can. J. Fish. Aquat. Sci., 51: 268-279.

MOLLOY, S., C. HOLLAND \& R. POOLE. 1995. Metazoan parasite community structure in brown trout from two lakes in western Ireland. $J$. Helminthol., 69: 237-242.

MONTAÑES, C. \& J. LOBÓN-CERVIÁ. 1986. Feeding ecology of a population of brown trout (Salmo trutta L.) in an aquifer-fed stream of Old Castile, Spain. Ekol. Pol., 34: 203-213.

NEVEAU, A. \& M. THIBAULT. 1977. Comportament alimentaire d'une population sauvage de truite fario (Salmo trutta L.) dans un ruisseau des Pyrènèes atlantiques, Le Lissuraga. Ann. Hidrobiol., 8: 111128

NEVEU, A. 1980. Relations entre le benthos, la derive, le rythme alimentaire et le taux de consommation de truites communes ( $S$. trutta L.) en canal experimental. Hydrobiologia, 76: 217-228.

OSCOZ, J., F. CAMPOS \& M. C. ESCALA. 2001. Alimentación del piscardo (Phoxinus phoxinus) en un río del norte de España. Ecología, 15: 285-291.

OSCOZ, J., M. C. ESCALA \& F. CAMPOS. 2000. La alimentación de la trucha común (Salmo trutta L., 1758 ) en un río de Navarra (N. España). Limnetica, 18: 29-35.

OSCOZ, J., P. M. LEUNDA, F. CAMPOS, M. C. ESCALA, C. GARCÍA-FRESCA \& R. MIRANDA. 2005. Spring diet composition of Rainbow Trout, Oncorhynchus mykiss (Walbaum, 1792) in the Urederra River (Spain). Ann. Limnol. - Int. J. Lim., 41(1): 27-34.

PENCZAK, T., E. KUSTO, D. KRYZANOWSKA, M. MOLINSKI \& E. SUSZYCKA. 1984. Food consumption and energy transformations by fish populations in two small lowland rivers in Poland. Hydrobiologia, 108: 135-144.

PILLANS, R. D., C. E. FRANKLIN \& I. R. TIBBETTS. 2004. Food choice in Siganus fuscescens: influence of macrophyte nutrient content and availability. J. Fish Biol., 64: 297-309.

POWER, G. 1992. Seasonal growth and diet of juvenile chinook salmon (Oncorhynchus tshawytscha) in demonstration channels and the main channel of the Waitaki river, New Zealand. Ecol. Freshw. Fish., 1(1): 12-25.

RAJASILTA, M. \& I. VUORINEN. 1983. A field study of prey selection in planktivorous fish larvae. Oecologia. 59: 65-68.
RINCÓN, P. A. \& J. LOBÓN-CERVIÁ. 1995. Use of an encounter model to predict size-selective predation by a stream-dwelling cyprinid. Freshwat. Biol., 33: 181-191.

RINCÓN, P. A. \& J. LOBÓN-CERVIÁ. 1999. Preysize selection by brown trout (Salmo trutta L.) in a stream in northern Spain. Can. J. Zool., 77: 755-765

RUTLEDGE, M. J. \& G. POWER. 1992. Annual variations on the diet of juveniles chinook salmon (Oncorhynchus tshawytscha) in the Waitaki river and the demonstration channels, 1982-1986. Ecol. Freshw. Fish, 1(2): 123-129.

SAVAGE, R. E. 1931. The relation between the feeding of the herring off the cast coast of England and the plankton of the surrounding waters. Fishery Investigation, Ministry of Agriculture, Food and Fisheries, Series 2, 12: 1-88.

SMITH, I. P., N. B. METCLFE, F. A. HUNTINGFORD \& S. KADRI. 1993. Daily and seasonal patterns in the feeding behaviour of Atlantic salmon (Salmo salar L.) in a sea cage. Aquaculture, 117: 165-178.

TACHET, H., M. BOURNAUD \& P. RICHOUX. 1984. Introduction à l'étude des macroinvertébrés des eaux douces (Systématique élémentaire et aperçu écologique), 2 édition. Université Lyon I. Association Française de Limnologie. Ministère de l'Environnement. $155 \mathrm{pp}$.

TIPPETS, W. E. \& P. B. MOYLE. 1978. Epibenthic feeding by rainbow trout (Salmo gairdneri) in the McCloud River, California. J. Anim. Ecol., 47: 549559.

VEHANEN, T., P. HYVARINEN \& A. HUUSKO. 1998. Food consumption and prey orientation of piscivorous brown trout (Salmo trutta) and pikeperch (Stizostedion lucioperca) in a large regulated lake. J. Appl. Ichthyol., 14: 15-22.

VIGNES, J. C. 1998. Observations sur le comportement trophique de jeunes saumons atlantiques dans le bassin de la Nivelle. Munibe, 50: 55-57.

VINYARD, G. L. 1980. Differential prey vulnerability and predator selectivity: the effects of evasive prey on sunfish (Lepomis) predation. Can. J. Aquat. Sci., 37: 2294-2299.

VOLLESTAD, L. A. \& R. ANDERSEN. 1985. Resource partitioning of various age groups of brown trout Salmo trutta in the littoral zone of lake Selura, Norway. Arch. Hidrobiol., 105(2): 177-185.

WENNHAGE, H. \& L. PIHL. 2002. Fish feeding guilds in shallow rocky and soft bottom areas on the Swedish west coast. J. Fish Biol., 61: 207-228. 
